\title{
Historical gardens of the Banat region
}

\author{
Noémi Melitta HEGEDÜS \\ Doctoral School of Technical University of Cluj-Napoca \\ e-mail: hegedusnoemi@yahoo.ro
}

\begin{abstract}
The aim of the article is the studying of a frequently seen phenomenon, which is the loss of value as far as some buildings and their surroundings are concerned, which, at the moment of their construction, held great historical and architectural value, but in time they have gradually lost their value due to political, social, and cultural changes. In the Banat region of the first half of the $19^{\text {th }}$ century, we can remark the dominance of the neoclassical style. The parks of the Banat region, apart from their role of satisfying the visual aesthetic appearances, are very well adapted to the place. They are unique, but the pattern after which they were conceived is common, according to the fashion of the era in which they were created. The subject of the research develops around the historical gardens belonging to certain historical monuments. The aim of researching these landscape arrangements is the investigation of the present-day situation and their evolution that has led to their actual transformation.
\end{abstract}

Keywords: castle, neoclassical style, historical value, monument

\section{Introduction}

In Timiș County, there are more than 30 castles and mansions, most of which have their origins in the $18^{\text {th }}-19^{\text {th }}$ centuries, the period in which the nobility began to appear in the Banat region, who were enchanted by the beauty of the buildings of the Habsburg Empire.

Most of the Banat communes or small towns link their evolution to a nobleman from the old guard, a count that, through charity works, by diligence and perseverance, succeeded in motivating the locals to work together for the construction of the settlement, thus establishing the infrastructure of these settlements and of the buildings of the premises of institutions indispensable to a community.

After the sale of the Habsburg crown domains at the end of the $19^{\text {th }}$ century and the emergence of large agricultural properties, the Hungarian, German, or 
Croatian nobles built castles, mansions, and summer residences in the Banat area, following the model of the Viennese royal courtyards, with neoclassical parks stretching over tens of hectares with a beauty specific to that area and period.

Many of these castles and mansions were demolished during the First World War. Others remained as a relic of the past, as a vestige of the old times.

A new era was born and another one, hundreds of years old, was reaching its end. Few of the nobles in the Banat area were able to accept these changes and lamented that the old times with imperial fasting and feudal privileges had come to an end.

The castles and mansions of these noblemen began to change, to adapt to the times and regimes that rapidly faded in the first half of the century. Some of these buildings died along with the owners. Others remained to survive. The price of survival was, however, the change.

Landscaping also suffered in recent decades by deliberate destruction, sometimes through ignorance and carelessness or due to the lack of material means of maintenance.

\section{Materials and methods}

We studied the territories situated between the Eastern Carpathians and Crişana, territories that have been predominantly under Western influence over time. The study period is delineated between the $17^{\text {th }}$ century and the $21^{\text {st }}$ century, these periods being studied from the appearance of these castles and gardens to the present.

The studied sites are analysed, following aspects such as: general data regarding the owners, construction stages, architectural style and constructors, study of the site, of the local relief and of the order of major elements of the arrangement, of the residence and its relationship with the exterior arrangements as well as of the exterior arrangement itself.

The study and documentation of the historical gardens in Banat began by researching them from ancient documents, books, maps, articles, and postcards. With the help of written documents, such as the personal documents of the noble families kept in the state archives or the specialized books, we managed to outline the story of every noble family in the possession of a mansion, castle, and garden attached to it [1].

Postcards represented a significant visual insight into the past, which, in addition to the maps studied, were a great help for a more accurate understanding of the planimetry of the gardens [2].

Also, the maps documented at cadastral offices [3] and the military maps [4] have been of great help in identifying the initial planimetry of the locality and the evolution of the gardens corresponding to mansions within these localities. 
All these documents underlie the study of these noble sites, which were finally outlined by a visit on the spot. The visitation of these sites was one of the most important steps of our research because the consultation of the present situation is decisive in the study of evolution of these gardens. But what we saw on the spot has had a negative and demoralizing impact in many cases, given the present state of these mansions, their castles and gardens, and what has remained from most of them.

The study was carried out on the architectural ensembles already classified as historical monuments as well as on those not classified but considered valuable based on the traces kept from the arrangement and/or its relation with the residence. So, we have visited 34 mansions and gardens, including 9 gardens classified as historical monuments and 25 gardens not included in the list of historical monuments.

The external arrangements and their related constructions were selected according to the coherent style, the current physical state, and the criteria of analysis such as historical analysis, stylistics, and the interventions carried out. The natural heritage assessment criteria have also influenced the selection of these gardens due to the valuable species of exceptional beauty discovered in situ, due to the evolutionary value, associative value, documentary, testimonial value, and landscape-land relationship [6].

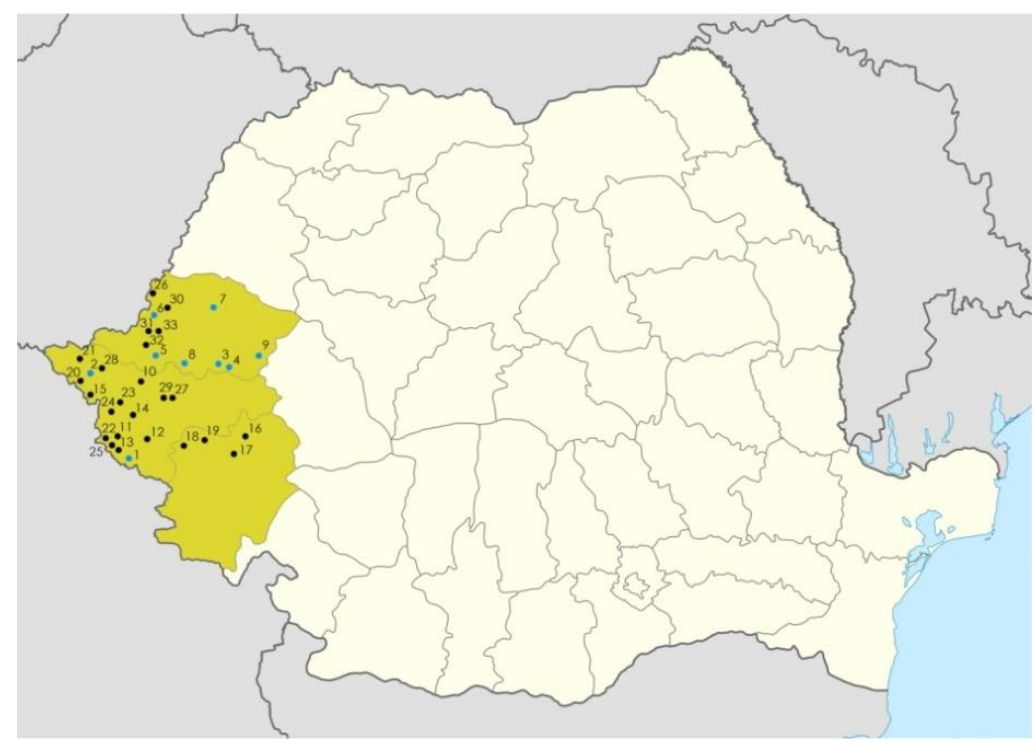

Figure 1. Map of the gardens visited in Caraş Severin, Arad, and Timişoara

During the on-site visit, the following mansions and gardens were studied: 
Parks ranked as historical monuments [7]: 1. Banloc - Timiş - Banloc Mansion Park; 2. Lovrin - Timiş - Lipthay Mansion Park; 3. Bulci - Arad Mocioni Castle Park; 4. Căpâlnăş - Arad - Teleki Castle Park; 5. Fântânele - Arad - The Kövér-Appel Castle Park; 6. Macea - Arad - Cernovici-Macea Castle Park; 7. Mocrea - Arad - Solymosy Castle Park; 8. Odvoş - Arad - Konopi Castle Park; 9. Petriş - Arad - Salbek Castle Park.

Parks not classified as historical monuments:

10. Carani-Timis-Saurau Féger; 11. Rudna - Timiş - Nikolics Residence; 12. Folea - Timiş - Beniczky Residence; 13. Livezile - Timiş - Gyertyánffy Residence; 14. Sag - Timiş - Rónay Residence; 15. Jimbolia - Timiş - Csitó Castle of the Csekonics family; 16. Zagujeni - Caraș Severin - Jakabffy - Juhász Castle; 17. Delinești - Caraș Severin - Brody Residence; 18. Ghertenis - Caraș Severin - Hollósi Mansion Park; 19. Valeapai - Caraș Severin - Atanasievici Castle Park; 20. Comloşu Mare - Timiş - San Marco Mansion Park; 21. Sânnicolau Mare - Timiș - Nako Mansion Park; 22. Foeni - Timiș - Mocioni Mansion Park; 23. Beregsau Mic - Timiș - Damaszkin István Castle Park; 24. Cenei - Timiș - Uzbasich Mansion Park; 25. Giera - Timiș - Gyetsanffy István Mansion Park; 26. Granicerii - Timiș - Csávossy Castle Park; 27. Izvin - Timiș Ottlik Péter Mansion Park; 28. Pesac - Timiș - Zichy Mansion Park; 29. Remetea Mare - Timiț - Ambrózy Castle Park; 30. Şimand - Arad - Kintyig Castle Park; 31. Şofronea - Arad - Purgly Castle Park; 32. Aradul Nou - Arad - Nopcsa Castle Park; 33. Zimandu Nou - Arad - Kintzig Castle Park; 34. Murani - Timiș Manaszy Barco Mansion Park.

\section{Results and discussions}

The research of the historical gardens in the Banat area is performed for mansions and castles built in most cases during the known period of the neoclassical style in this area of the country. The neoclassical style requires a solemn image with an elegant refinement and exuberance of details and decorations. It is the favourite style of the aristocracy and of the bourgeoisie, offering an impressive image of the exterior and interior architecture, worthy of a social status, which also exposes its grandeur in this way.

The neoclassical period adopts the style of English landscapes with sinuous alleys, and the Banat castle parks are built in most cases in the neoclassical style. The layout is not geometric, and there are no rigorous lines or rules, strict alignments. The parks of these castles are characterized by trees and shrubs organized in a more relaxed style, with many exotic species brought to the liking of the owners, some arrangements reaching the appearance and character of the dendrological parks. 
In addition to the importance of the building, the landscape architecture was equally important when it came to power and grandiosity. The arrangement of the grand entrance provided an impressive and important framework in order to bring the beauty of the building to the forefront [8].

Currently, most of these mansions and castles are left in a state of advanced degradation, most of which are abandoned, but some are used to shelter public functions, rarely private.

The gardens of these buildings, classified as historical monuments, are in most cases missing, without any specific landscaping. In the case of gardens classified as historical monuments, the only testimonies that could serve as a guide are the high vegetation elements, rare trees, which have been preserved in most gardens. The low and medium vegetation or architectural landscaping elements are in most cases unidentifiable.

All these gardens and mansions studied have a significant geographic significance because they have a noble family behind them, with the help of which these castles and gardens have emerged. In most cases, these nobles influenced the development of the locality in which they had built them by possessing these domains, and in some cases even the entire locality was under their control.
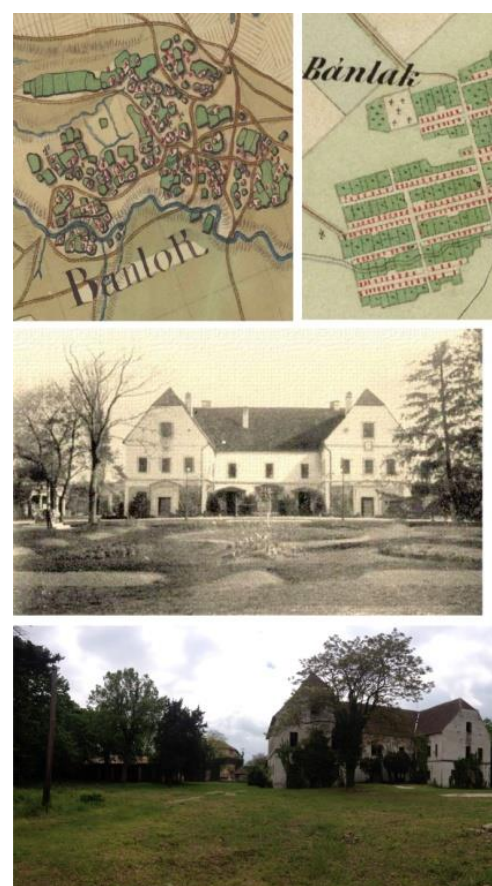
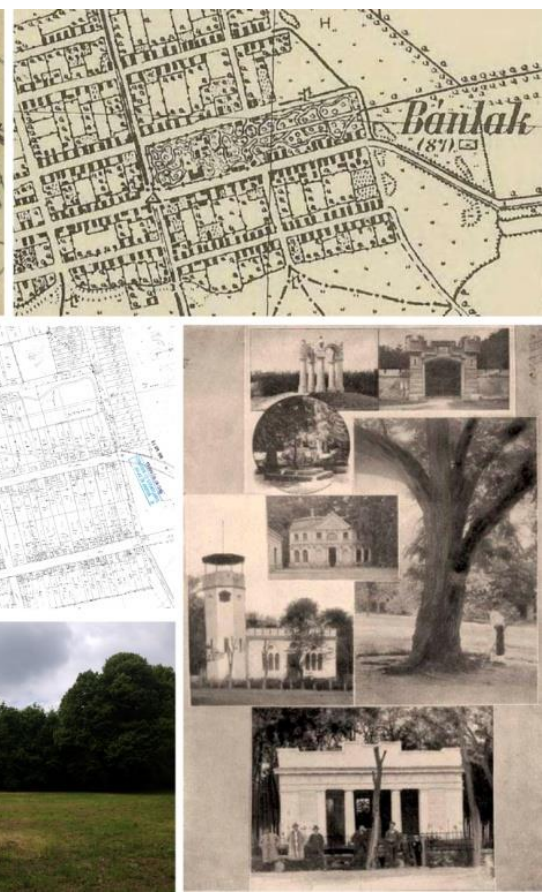

Figure 2. Case study - Banloc Castle Garden - a garden ranked as a historical monument postal cards of the epoch [9], cadastral [3], military maps [4], and the author's photos 
In the case of gardens not classified as historical monuments in most of the studied cases, we cannot observe a coherent landscaping because the traces of these gardens no longer exist. The planimetric existence according to a certain typology of settlement of these arrangements in relation to the castle can be ascertained, but the planimetry of the epoch garden is not noticeable.

The only footprint of the Epoch Park is in most cases the existence of high vegetation, positioned only in certain areas on the site, not necessarily having a visible logic, to present us a testimony of what used to be once.
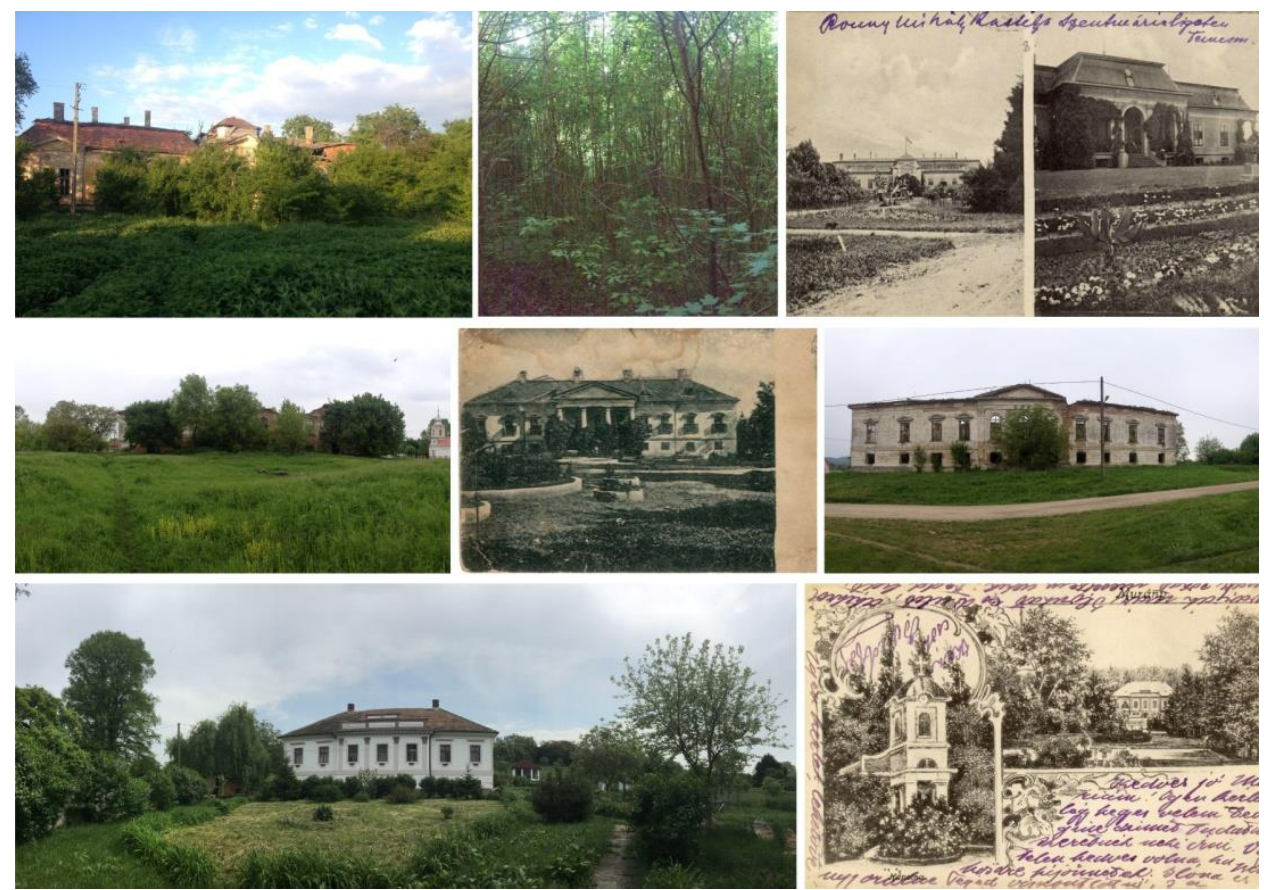

Figure 3. Case studies - Gardens not classified as historical monuments:

Ronay Castle Garden in Șag, Timiș County - Epoch Postcards [9]; Athanaszievich Castle Garden in Valeapai, Caraș Severin County - Epoch postcards [10]; Manaszy Barco Castle Garden in Murani, Timiș County - Epoch postcards [11] - the author's photos

Many of these gardens have been designed by specialists brought from outside the country, especially by Austrian craftsmen and architects, and in most cases these are based on Viennese gardens and courtyards.

On the cadastral maps, they appear as large landscapes with spectacular dimensions, which were located mostly behind the construction (the "back" being the main access façade), stretching spectacularly all along the alleys and long promenades, with a game of lines that give up any rigidity, rigour, and symmetry, 
leading the eye to oval shapes, thus giving the landscape image a planimetric freedom and a visual emotion when unravelling these unplanned paths.

The present situation is less readable in terms of frequency, rarity, and uniqueness due to the abandoned and wildlife situation of these gardens.

Of the number of gardens visited, 16 are made before and between 1775 and 1830, which offers membership to a limited series for a historical-geographic area and for a historical period, also offering a typicality for this area through the style of the adopted age.

According to the statistics adopted on these studied gardens, given their present condition as compared to their original image, we have made a diagram showing the following:

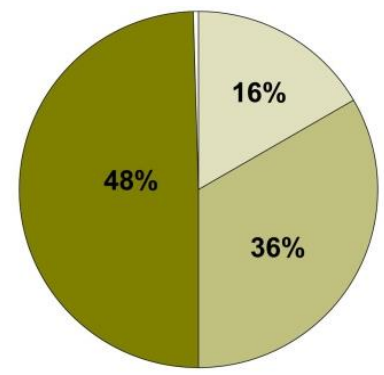

Figure 3. The original footprint of the existing historical gardens

The situation of the gardens of the mansions currently visited is demoralizing since $48 \%$ of the studied cases no longer show signs of landscaping of the original garden of the epoch. $36 \%$ of the gardens have landscapes with vegetal elements but only with high vegetation and currently existing landscape architectural elements of which less than $50 \%$ of the landscaping model of the original garden of the epoch.

In case of $16 \%$ of these gardens, landscaping with vegetal elements can be observed, namely with high vegetation and currently existing landscape architectural elements of which 50\% according to the pattern of landscaping of the original garden of the epoch. According to the study carried out within our research, there is no entirely existent landscaping according to the landscaping model of the original garden of the epoch.

\section{Conclusions}

Focusing on the historical gardens of mansions, castles, and noble residences, the present study outlines an image of Banat sites selected from those already classified as historical monuments and from those not classified but considered 
valuable based on the traces kept in the arrangement and/or their relationship with the built residence.

Due to the fact that the information accumulated over time and the few and disparate studies on the historical gardens of the Banat area, the present study comes on a relatively free field, adding a supplement to the historiography of the problem, while leaving the possibility for further research on the topic.

The present study is an attempt to show the charm of rural residences, focusing on its landscaping, which, though humiliated by fate, proves that built history cannot be forgotten.

Today's specialists are interested in these gardens, which have been and are unmatched values and present a testimony of the historical past, being at least as valuable as the construction they are accompanying.

After years of ruin and forgetfulness, we hope that with the help of specialists in the field we can offer a new chance for the revitalization and continued survival of these gardens.

\section{References}

[1] Borovszky, Samu (1911), Magyarország vármégyei és városai enciklopediája: Torontál vármegye. Budapest; (1914), Magyarország vármegyéi és városai enciklopediája: Temes vármegye. Budapest.

[2] Horváth, Hilda (2010), Stílus, szellem, tradició. A történelmi Magyaroszág kastélyai. Várpalota: Szindbad Nonprofit Kft.-Trianon Múzeum Alapítvány.

[3] Timiş Office of Cadastre and Land Registration; Arad Office of Cadastre and Land Registration.

[4] The Josephine Topographic Map (in German: Josephinische Landesaufnahme), also called "The first topographical map".

[5] The second topographical map from 1806 (Zweite oder Franziszeische Landesaufnahme). The third topographical map made between 1869 and 1887 (in German: Franzisco-Josephinische Landesaufnahme or Dritte Landesaufnahme) - "Franciscan Josephine Topographical Map", The "Magyar Királyság" map achieved between 1869 and 1887.

[6] Fejérdy, Tamás (2014), Instituțiile protecției patrimoniului construit (Institutions of built heritage protection). Specialist manual for students and postgraduate students. Postgraduate course of specialization in the rehabilitation of the built heritage - continuous professional training and development program in the field of rehabilitation of historical monuments. Transylvania Trust 20-22.

[7] List of historical monuments in Romania. (2015) - Ministry of Culture and National Patrimony.

[8] Julean, Ionuț (2006), Șase castele neoclasice în Banat (Six neoclassical castles in Banat). Revista logiA 9, 67-76. F.A.U. Cluj-Napoca.

[9] Magyarország vármegyéi és városai [a teljes Borovszky]. Budapest: Országos Monográfia Társaság. A Magyar Tudományos Akadémia - online edition [oszk.hu]. Accessed on: 16 August 2016.

[10] Picture taken from the article by Anca Erena: The story of the Risz Family and of the Atanasievici Castle - 15.05.2013. http://expressdebanat.ro/. (Accessed on: 2 September 2016).

[11] Horváth, Hilda (2010), Stílus, szellem, tradició. A történelmi Magyaroszág kastélyai. Várpalota: Szindbad Nonprofit Kft.-Trianon Múzeum Alapítvány [CD]. 